\title{
Research
}

\section{Economic Benefits Generated by Protected Areas: the Case of the Hoge Veluwe Forest, the Netherlands}

\author{
$\underline{\text { Lars Hein }}^{1}$
}

\begin{abstract}
Eliciting the economic benefits provided by protected areas is important in order to ensure that they are properly considered in policy and decision making. There are relatively few studies that provide a comprehensive overview of the economic benefits provided by European forest ecosystems, in spite of the large share of forests in the protected area system in most countries. An economic valuation of the ecosystem services supplied by the Hoge Veluwe forest in the Netherlands is presented. The Hoge Veluwe forest is one of the largest and most well-known protected areas in the country. The services included in the study are wood production, supply of game, groundwater recharge, carbon sequestration, air filtration, recreation, and nature conservation. A conservative estimate of the total economic benefits generated by the forest is around $2000 \mathrm{Euro} / \mathrm{ha} /$ year, which is more than three times higher than the per hectare-value generated by nearby agricultural land. The study provides an analysis of the economic value of eight ecosystem services, discusses the uncertainties of the value estimates, and examines the implications for financing protected area management.
\end{abstract}

Key Words: ecosystem services; Europe; forest; Hoge Veluwe forest; protected area; valuation

\section{INTRODUCTION}

In recent years, there has been a strong increase in interest in the analysis and valuation of ecosystem services (e.g., Turner et al. 2000, Daily and Matson 2008, Daily et al. 2009). Following up on the Millennium Assessment (Millennium Assessment 2005), various authors have further developed the concept of ecosystem services and provided guidance on how the concept can be used to support policy and decision making (e.g. Boyd and Banzhaf 2007, Asink et al. 2008, Turner and Daily 2008, Carpenter et al. 2009, Nelson et al. 2009). In the context of protected area management, ecosystem services analysis and valuation is important for two main reasons.

First, because the benefits provided by protected areas are often not quantified, there is a risk that these benefits are underestimated in policy making (e.g., Balmford and Whitten 2003, Dearden et al. 2005, Carpenter et al. 2006, Emerton et al. 2006, Tallis et al. 2009). The current economic crisis is leading to further pressure on government budgets, and on the budget available to maintain existing protected areas and create new protected areas. In the Netherlands, policy makers are currently considering major budget cuts for nature conservation (Planbureau voor de Leefomgeving 2010). Recently, the Dutch government announced its intention to halve the budget of the State Forest Service, which is the largest manager of protected areas in the Netherlands with 250,000 ha, in the course of the next two years. Given that the need to cut back public spending also exists in many other countries, similar pressures on budgets for protected area management may arise elsewhere.

Second, integrated ecosystem management, which aims to combine the provision of different types of ecosystem services, is becoming increasingly important for protected areas (Gaston et al. 2008, Palomo et al. 2011). It is now widely recognized that, in addition to biodiversity conservation, protected areas also provide a number of other public services such as recreation, reducing air pollution levels through deposition of fine particles, and the recharge of groundwater aquifers (e.g., Balmford et al. 2002, Parviainen and Frank 2003). In order to formulate and implement management 
approaches that support the supply of multiple services, quantitative insight into the complete bundle of services and values supplied by protected areas is therefore required.

In spite of the progress recently made in understanding the values of ecosystem services in a range of contexts, there are relatively few studies providing a comprehensive analysis of the bundle of ecosystem services generated by European protected areas (e.g. Millennium Assessment 2005, Gaston et al. 2008, Jongeneel et al. 2008). Studies on European forest ecosystem services, in particular, are rare (Elsasser 2007). A literature search revealed one European study analyzing the bundle of forest ecosystem services at the national scale (Willis et al. 2003) and a limited number of studies analyzing one or a few services supplied by a specific forest (e.g. Brauer 2005). This is a main gap in our understanding of the benefits provided by ecosystems, in particular because most of the terrestrial protected areas in Northwestern Europe are dominated by forests (Planbureau voor de Leefomgeving 2009).

Hence, there is a need to increase the understanding of the economic benefits supplied by protected forest ecosystems, with consideration of the various constraints to the economic valuation of ecosystems (e.g. Bockstael et al. 2000, Soma 2006, Spash 2008). The objective of this study is to analyze the economic value of the bundle of ecosystem services provided by the Hoge Veluwe forest in the Netherlands. The Hoge Veluwe is one of the largest and most well-known protected areas of the country, covering a forest and heather landscape of about 5500 ha. The services supplied by the park are representative of the services supplied by other protected forest areas in the country. The area has been selected for this case study because its ecosystems are representative of many terrestrial protected areas in the Netherlands and in neighboring countries, and because of the relatively high data availability.

An analysis and economic valuation of eight ecosystem services supplied by the park under current management will be presented, including three regulating services. A number of different valuation methods are applied, and the applicability of, and uncertainties related to, these valuation methods are analyzed. The implications of the retrieved economic values for decision and policy making on forest conservation are also discussed. Specifically, the possibilities of protected areas capitalizing on ecosystem services supply through Payment for Ecosystem Services schemes are discussed, and potential implications for protected area managers faced with dwindling government support are briefly analyzed.

\section{METHODS}

\section{Case study area}

The Hoge Veluwe is a national park located in the center of the Netherlands (Figure 1). The park is located on the undulating terminal moraine deposits characteristic of the center of the Netherlands. The park is made up of approximately 5500 ha of forest, heather, and drift sand and is one of the largest nature reserves in the Netherlands. Stands of both pine and deciduous forests are present, with production forestry concentrated in the pine forests. Animals in the park include wild boar, red deer, badger, and roe deer. The area has been continuously protected since 1909, when it was established under the private ownership of the Kröller-Müller family. In 1935, the family transferred park ownership to an independent foundation, which has managed the park ever since. Inside the park is the Kröller-Müller art museum, which harbors an internationally renowned collection of Dutch and international paintings and sculptures. The park is one of the most well-known national parks in the Netherlands, and receives around 500,000 visitors each year.

All major ecosystem services provided by the Hoge Veluwe are included in this study, as identified on the basis of a literature review and interviews with the park management. These services are: (1) wood production, (2) supply of game (wild boar and deer), (3) groundwater infiltration, (4) carbon sequestration, (5) air pollution removal, (6) recreation, (7) recreational hunting, and (8) biodiversity conservation.

\section{Valuation approach}

The study follows the general approach of the Millennium Ecosystem Assessment (Millennium Assessment 2003, 2005) with regard to the identification, analysis, and valuation of ecosystem services. The object of the valuation is the forest ecosystem within the park perimeter, including the forest, heather, drift sand and grassland ecosystems, but excluding the small patch of agricultural land in the forest (46 ha) and the camping site and sport 
Fig. 1. Map and location of the Hoge Veluwe national park

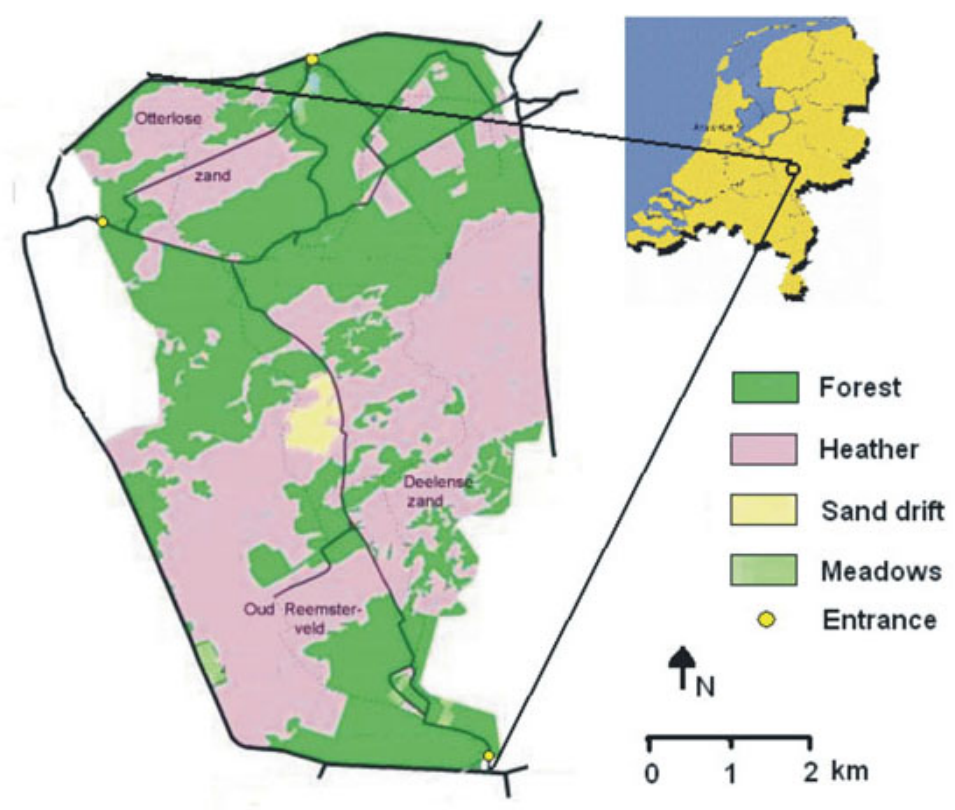

field located within the park boundaries (110 ha). All services are quantified in ecological or physical units, such as for example, amount of wood harvested and the annual number of visitors. Three types of ecosystem services are distinguished (cf. Millennium Assessment 2003): provisioning services, involving the goods that can be harvested in an ecosystem; regulating services, reflecting the fact that ecosystems can regulate essential ecological and climatological processes; and cultural services, which refer to non-material benefits provided by ecosystems. Supporting services are not included as this would lead to double counting of values (cf. Hein et al. 2006).

Second, the services are valued in monetary terms. Services may either provide direct use, indirect use, non-use, or option value. Direct use value is generally associated with the provisioning services as well as recreation (Millennium Assessment 2003), and indirect use value with the regulating services. Non-use value is generally linked to the biodiversity conserved in an ecosystem and can only be quantified using contingent valuation or related methods (Garrod and Willis 1997, Nunes and Van den Bergh 2004). Option value relates to keeping the option open of converting the ecosystem at a later point in time, and depends on risk aversiveness (Cicchetti and Freeman 1971). Even though conservation of the Hoge Veluwe forest is likely to have an option value, this value is difficult to assess, and not further considered here. Hence, the focus is on the direct use, indirect use, and non-use value provided by the forest ecosystem of the Hoge Veluwe national park.

Economic valuation of ecosystem services requires analysis and aggregation of the consumer and producer surpluses generated by these services (Freeman 1993). Where data were available, this study values ecosystem services based on estimation and aggregation of producer and consumer surpluses. The producer is, in all cases, the foundation managing the Hoge Veluwe park. Around $80 \%$ of the income of the foundation is derived from entrance fees, and the remainder is composed of revenues from land lease to farmers, two restaurants and a camping site, the sale of wood and deer and wild boar meat, and government subsidies for nature conservation. As mentioned, the farmland, restaurants and camping site are not further considered in this study.

For some services, in particular the regulating services of groundwater infiltration, carbon sequestration, and air pollution removal, consumer and producer surpluses could not be calculated, and alternative, though less accurate, valuation methods 
have been applied. The specific valuation approach applied to each of the identified ecosystem services is explained in the text. The biodiversity conservation service is not analyzed in monetary terms, in view of the various difficulties related to providing a meaningful monetary indicator of this service (e.g. Spash and Hanley 1995). All prices and values are converted to 2007 euro, using $2 \%$ annual inflation.

\section{ECOSYSTEM SERVICES: PHYSICAL SUPPLY}

The ecosystem services supplied by the Hoge Veluwe protected area are analyzed in physical terms: (1) wood production, (2) supply of meat, (3) groundwater infiltration, (4) carbon sequestration, (5) air pollution removal, (6) recreation, (7) recreational hunting, and (8) biodiversity conservation.

\section{(1) Wood production}

The Hoge Veluwe comprises around 613 ha of deciduous forest, and 2282 ha of coniferous forest. Wood production is concentrated in the coniferous forests, as the management of the park is aimed at increasing the share of native deciduous trees. Therefore, the main trees harvested are pine (mostly Pinus sylvestris), larch (Larix decidua), and douglas spar (Pseudotsuga menziesii). A range of different wood qualities is harvested. The best wood is used for the production of construction wood in local saw mills, medium quality wood for pellets, and the lowest quality wood for the production of board. The total amount of wood harvested amounts to $2600 \mathrm{~m}^{3}$ of saw wood, $1200 \mathrm{~m}^{3}$ of medium quality wood and $8000 \mathrm{~m}^{3}$ of low quality wood per year (B. Boers, The Hoge Veluwe National Park Foundation, 2008, personal communication).

\section{(2) Meat from hunting}

The Hoge Veluwe allows hunting by a hunters' association ("St Hubertus"). The park itself sells all meat that is harvested by this association in a shop inside the park. The main meat sold is red deer, roe deer, and wild boar. The park has established a target population for red deer (200 individuals) and wild boar (50 individuals) based on the carrying capacity of the vegetation. The annual surplus is allowed to be shot. The relatively low density of supported wild boar is related to the dominance of coniferous forest, which provides little food to these animals. A total of 300 animals are shot each year, including roe deer, yielding around $10,000 \mathrm{~kg}$ of gross animal weight, of which around half is sold as meat.

\section{(3) Groundwater infiltration}

The Veluwe moraine, which includes the Hoge Veluwe forest, serves as an important area for groundwater replenishment. Drinking water wells are located on and around the Veluwe and supply water to the towns and villages in the area, for some 1.5 million people in total. For the overall Veluwe area, the average annual groundwater replenishment is around $400 \mathrm{~mm}$ per year (Tauw 2003). However, groundwater replenishment varies as a function of the vegetation cover. For the Hoge Veluwe, the groundwater replenishment is estimated as a function of the land cover (see Table 1). The total net infiltration in the Hoge Veluwe park is calculated to be around 16.8 million $\mathrm{m}^{3}$. The average per ha infiltration in the Hoge Veluwe forest equals $305 \mathrm{~mm} / y e a r$, which is somewhat lower than for the overall moraine because of the relatively high pine coverage in the park.

\section{(4) Carbon sequestration}

Carbon sequestration depends on the dynamics and management of the vegetation. It is generally high in young forests, and declining in mature forests. Management of the forest stands in the park is as follows. Logging is concentrated in coniferous forest, and takes place predominantly in stands of pine $(70 \%)$ and douglas spar $(20 \%)$. The remainder $(10 \%)$ of logging takes place in deciduous forest. Clear-cut of forest stands is exceptional, and the large majority of the logging is selective logging (B. Boers, Hoge Veluwe National Park Foundation, 2008, personal communication). The annual increment is highest in coniferous forest stands, at around $7 \mathrm{~m}^{3} /$ ha/year (Nationale Park de Hoge Veluwe 2005). In deciduous forest, the annual increment is only $4 \mathrm{~m}^{3} / \mathrm{ha} /$ year (Nationale Park de Hoge Veluwe 2005). The total annual increment in the forests of the park is therefore around 18,430 $\mathrm{m}^{3} /$ year. Of this amount, $11,800 \mathrm{~m}^{3} /$ year is harvested. Hence, the total increase in biomass in the Hoge Veluwe park can therefore be estimated at $6630 \mathrm{~m}^{3}$, i.e., 3580 tons of wood per year, based 
Table 1. Groundwater replenishment in the Hoge Veluwe.

\begin{tabular}{lrrr}
\hline \hline Land cover unit & Area (ha) & $\begin{array}{r}\text { Net infiltration } \\
(\mathrm{mm} / \text { year })\end{array}$ & $\begin{array}{r}\text { Groundwater } \\
\text { replenishment } \\
\left(1000 \mathrm{~m}^{3}\right)^{\dagger}\end{array}$ \\
\hline Drift sand & 59 & $740^{\dagger}$ & 437 \\
Heather & 2279 & $310^{\dagger}$ & 7065 \\
Grassland & 48 & $280^{\ddagger}$ & 134 \\
Arable land & 46 & $280^{\ddagger}$ & 129 \\
Deciduous forest & 613 & $362^{\dagger}$ & 2219 \\
Coniferous forest & 2280 & $283^{\dagger}$ & 6452 \\
Open water & 15 & $150^{\S}$ & 23 \\
Other (camping area, sport field, buildings) & 110 & $280^{\ddagger}$ & 308 \\
Total & 5450 & & 16767 \\
\hline
\end{tabular}

†Source: Gehrels and Dolman (1996) ‡Source: Bastiaanssen and Roozekrans (2003) ${ }^{\S}$ Source:

Waterwatch (2007) 'Based on a multiplication of columns two and three.

on a specific weight of $540 \mathrm{~kg} / \mathrm{ton}$, the weighted average for the harvested tree species. Most of the forest stands are relatively open, and no significant decline in annual increment can be expected in the coming decade (Nationale Park de Hoge Veluwe 2005). The water content of freshly sawn wood (mostly pine) is assumed to be $50 \%$, and the average carbon content of dry wood is also assumed to be $50 \%$ (Ragland et al. 1991). Therefore, the total amount of $\mathrm{CO}_{2}$ sequestered annually in the above ground biomass of the Hoge Veluwe park is currently $0.25 * 3580=900$ tons $\mathrm{C} /$ year, or 3280 ton $\mathrm{CO}_{2}$ /year. This amounts to $900 / 2892=0.31$ ton $\mathrm{C} /$ ha/year.

\section{(5) Air pollution removal}

Air pollution arising from particulate matter (in particular the smallest fraction of PM: PM10 with a diameter $<10 \mu \mathrm{m}$ ) is a major environmental and health problem in the Netherlands (RIVM 2005). Air pollution removal takes place through the interception of PM by leaves (dry deposition). The total amount of particulate matter deposited on a certain site can be estimated as a function of the area, deposition velocity, time period, and average ambient PM10 concentration, according to the formula $\mathrm{PM} \downarrow=\mathrm{A} * \mathrm{~V}_{\mathrm{d}}{ }^{*} \mathrm{t}^{*} \mathrm{C}$, in which $\mathrm{PM} \downarrow=$ deposition of PM10 $(\mathrm{kg}), \mathrm{A}=$ area $\left(\mathrm{m}^{2}\right), \mathrm{V}_{\mathrm{d}}=$ deposition velocity as a function of LAI $(\mathrm{m} / \mathrm{s}), \mathrm{t}=$ time (s), and $\mathrm{C}=$ ambient PM10 concentration (kg/ $\left.\mathrm{m}^{3}\right)$ (Becket et al. 2000, Powe and Willis 2004). The deposition velocity depends on the vegetation type, and in the absence of better data is assumed to correspond to the deposition velocities measured in England, which has generally comparable types of deciduous and coniferous forest (Powe and Willis 2004). The PM10 concentration (C) is assumed to be $27.9 \mu \mathrm{g} / \mathrm{m}^{3}$, which is the average concentration of the nearby PM10 monitoring station in Wekerom over the period 2003-2006 (RIVM 2006). The average dry deposition of PM10 in the Veluwe is therefore estimated at $37 \mathrm{~kg} / \mathrm{ha} /$ year (see Table 2).

\section{(6) Recreation: hunting}

Hunting is practiced from August to December, with the double aim of generating revenue and keeping the populations of red deer, wild boar, and roe deer in line with the carrying capacity of the park. Every 
Table 2. PM10 deposition in the Hoge Veluwe park

\begin{tabular}{lrrr}
\hline \hline Land cover unit & $\begin{array}{r}\text { Area } \\
(\mathrm{ha})\end{array}$ & $\begin{array}{r}\text { Deposition velocity } \\
(\mathrm{m} / \mathrm{s})\end{array}$ & $\begin{array}{r}\text { PM10 deposition } \\
(1000 \mathrm{~kg} / \mathrm{year})\end{array}$ \\
\hline Sand-drift & 59 & 0 & 0 \\
Heather & 2279 & 1 & 20 \\
Grassland & 48 & 1 & 0 \\
Arable land & 46 & 1 & 0 \\
Deciduous forest & 613 & 8.2 & 17 \\
Coniferous forest & 2280 & 0 & 0 \\
Open water & 15 & 1 & 1 \\
Other (camping area, sport field, buildings) & 110 & & 200 \\
Total & 5450 & & 0 \\
\hline
\end{tabular}

year 300 animals are shot by the "St Hubertus" Hunters' Association, but the hunters have to hand the animals back to the park management without being paid for them. The foundation managing the park sells the meat.

\section{(7) Recreation: walking, cycling}

The visitors to the Kröller-Müller museum located inside the park also pay the entrance fee to the national park. Given the focus of this study on the forest ecosystem, all visitors to the museum have been excluded from the analysis, even though many of them may combine a visit to the museum with a stroll in the park. The total number of visitors to the park in 2007 was 520,000, of which 215,000 also visited the museum. Therefore, for the purpose of this study, it is assumed that 305,000 people visited the park for the purpose of recreation in the forest ecosystem. Note that the recreation service of the park also supports the local tourism industry, in particular hotels and restaurants in the vicinity of the park. For instance, a visitor survey carried out by the park management in 1994 (Jansen et al. 1994) found that $39 \%$ of the visitors to the park arrived from a camping site, recreational home or hotel. Valuation of this contribution of the park to the local economy requires analyzing the producer surplus accruing to the local hotels and restaurants, as well as the consumer surplus accruing to the visitors of the hotels and restaurants. However, these local benefits are not further considered in this study, since this valuation study focuses on ecosystem services generated within the park boundary. In addition, it is unclear which proportion of visits to these hotels and restaurants can be assigned to the presence of the park, given the availability of several other parks in the area.

\section{(8) Biodiversity}

The Hoge Veluwe park is actively managed in order to maintain its biodiversity. Since the park lacks large carnivores, with only the fox and pine marten present, there is culling of wild boar and deer populations. There is also annual mowing of the grasslands of the park, with the aim of maintaining butterfly habitat, as well as regular removal of the topsoil and associated nutrients in heather in order to maintain the vegetation. As a consequence of its relatively large size and the continuous active management over a period of several decades, the park is highly important for a range of ecosystem types and threatened species. The park contains 59 ha of drift sand ecosystems that are relatively rare in the Netherlands, 48 ha of nutrient-poor 
grasslands, and some 250 ha of old-growth, though not primary, deciduous forest. In terms of species diversity, mammal populations in the park that are rare at the national level include the mouflon and the badger, as well as several species of bats. Last year, the park had the only breeding couple of the wryneck (Jynx torquilla) in the Netherlands as well as 67 couples of the nightjar (Caprimulgus europaeus), which makes the park one of the most important habitats for this species in the country. The black grouse (Tetrao tetrix) was recently reintroduced in the park. In total, the number of breeding birds in the park varied from 61 to 75 species in the last five years. There are also 30 butterfly species (including the rare Argynnis niobe, Argynnis aglaja and Hipparchia semele), 21 dragonfly species, and five reptiles, including all three snakes occurring in the Netherlands.

\section{VALUATION OF ECOSYSTEM SERVICES}

An estimate is presented of the economic value of the ecosystem services supplied by the Hoge Veluwe protected area, including: (1) wood production, (2) supply of meat, (3) groundwater infiltration, (4) carbon sequestration, (5) air pollution removal, (6) recreation, (7) recreational hunting, and (8) biodiversity conservation. Different valuation approaches are used for these different services, as will be described.

\section{(1) Wood}

As with any ecosystem service, valuation requires estimation of the producer and consumer surplus. Under a number of conditions, the individual producer surplus can be calculated on the basis of the total revenues minus the production costs (Varian 1993). The producer is, in this case, the foundation managing the Hoge Veluwe forest. The foundation sells the wood almost exclusively as "standing stock", which means that the buyer bears the costs of harvesting the trees and transporting them out of the park. Bidding for the standing stock of wood is competitive. Since logging and transportation costs are born by the logging company, the price paid by the logging company to the park for the standing stock represents the net benefit generated by this service to the foundation managing the park. The price of the wood in the park, as it stands, is as follows. High quality wood fetches $€ 90 / \mathrm{m}^{3}$, medium quality $€ 40 / \mathrm{m}^{3}$, and low quality wood only $€ 9 / \mathrm{m}^{3}$. The total value of the service is therefore: $2600 * 90+1200 * 40+8000 * 9=$ $€ 354,000 /$ year. The production of wood from the park is very small compared to the national market supply. There is a much larger supply of wood from forests managed mostly as production forests, including in the vicinity of the park, as well as from sources abroad, in particular Scandinavia and Russia. The total wood market in the Netherlands including all wood products except furniture amounts to around $€ 1.3$ billion per year (Central Bureau for Statistics the Netherlands 2009a). Therefore, it can be assumed that wood production in the Hoge Veluwe park does not influence the price of wood on the Dutch market, and that there is no consumer surplus related to the provisioning of this ecosystem service by the park. It is assumed that the net benefit of wood production for the foundation also represents the net benefit for Dutch society as a whole, i.e., the economic value generated by this service.

\section{(2) Meat from hunting}

Both producer and consumer surplus are examined. Again, the producer is the foundation managing the park, and the consumers are Dutch society as a whole. All hunting is carried out by the hunters' association. The hunters' association is required to hand over the hunted meat to the foundation for free; in other words, the association pays for the right to hunt in the forest without being allowed to keep the meat. There is therefore a strict distinction between meat production from hunting and the recreational value of hunting in the park, which will be further discussed, and potential double counting between these services is avoided. Because the foundation does not have to pay for obtaining the meat, the production costs related to hunting are zero. The foundation sells the hunted animals to a local butcher. The net revenue for the park related to the sale of hunted, but not slaughtered, animals is around $€ 50,000$ per year (B. Boers, Hoge Veluwe National Park Foundation, 2008, personal communication). As with the case of wood production, the production of deer and wild boar meat in the park is very small compared to the national supply, and the consumer surplus is assumed to be zero. The net benefits for the park are therefore assumed to represent the economic value of this service. 


\section{(3) Groundwater infiltration}

Total groundwater replenishment in the Hoge Veluwe park is 16.8 million $\mathrm{m}^{3} /$ year, as indicated earlier. Data from the local drinking water company show that $29 \%$ of the water infiltrated in the Veluwe forest is used for drinking water production (Vitens 2008) and it assumed that this same percentage applies to the water that infiltrates in the Hoge Veluwe forest, which is somewhat conservative given that there are three main extraction wells just adjacent to the park.

Valuation of this regulation service is not straightforward. The consumer surplus for drinking water can be expected to be very high because drinking water is essential to people's lives and it is not substitutable. However, in the case of the Hoge Veluwe forest, there are other sources of drinking water that would be used in the absence of the park, in particular water from the nearby river Rhine. Therefore, the replacement cost method is selected for valuing this service. The replacement cost method does not reflect preferences, and therefore provides a different indicator of economic value compared to the two services valued previously (see e.g. Freeman 1993 for details). The National Research Council (NRC 2004) states three requirements that need to be met in order for the replacement cost method to be applied: (1) there is an alternative that offers the same service, (2) this alternative would be used in the absence of the ecosystem service, and (3) the considered alternative is the least-cost alternative. Following NRC (2004), the least-cost option to substitute the infiltration service is examined. Consequently the three requirements specified in NRC (2004) are met for this case study. The alternative option is to use water from the nearby river Rhine and treat it for use as drinking water; in fact, this is precisely what happens $25 \mathrm{~km}$ downstream, where Rhine water is used for drinking water production. Given the degree of pollution of the river, this is expensive relative to using groundwater from the Hoge Veluwe. In line with NRC (2004), the benefits generated by using water from the Hoge Veluwe are assumed to equal the avoided costs of treating Rhine water. Compared to the costs of treating groundwater, the average costs for purification of river water are $€ 0.40 / \mathrm{m}^{3}$ higher (Mulder 1998, Vewin 2007). Hence, the economic value of water infiltrated in the Hoge Veluwe is estimated to equal these avoided costs, i.e., $€ 0.40 / \mathrm{m}^{3}$, resulting in a total economic value of the service of $€ 1.95$ million/ year.

\section{(4) Carbon sequestration}

The total amount of $\mathrm{CO}_{2}$ sequestered annually in the above-ground biomass of the Hoge Veluwe park is 3280 tons $\mathrm{CO}_{2}$ /year, as demonstrated earlier. Estimates for the economic value of a unit of carbon sequestered vary widely. Indications of the marginal value of sequestered carbon can be obtained from either prices at which $\mathrm{CO}_{2}$ is traded in existing carbon markets, or from damage cost assessments. By far the largest carbon trading scheme is the EU Carbon Trading Scheme (ECTS), which does not apply to forestry, however. Since its inception in 2005, a ton of $\mathrm{CO}_{2}$ has traded for less than 1 euro/ ton up to 30 euro/ton in the EU market, with recent prices in the order of $€ 10-15$ per ton $\mathrm{CO}_{2}$. For carbon capture through reforestation schemes, the price of $\mathrm{CO}_{2}$ differs for $\mathrm{CO}_{2}$ capture compliant with Kyoto or under a voluntary agreement, with the price for voluntary credits being lower, ranging from US\$ 2 to 4 per ton $\mathrm{CO}_{2}$ (World Bank 2008). Based on a review of studies that analyze the marginal costs of greenhouse gas emissions, Tol (2005) finds that "it is unlikely that the marginal damage costs of $\mathrm{CO}_{2}$ emissions exceed $\$ 50 / \mathrm{tC}$ (i.e., US $\$ 14 /$ ton $\mathrm{CO}_{2}$ ) and are likely to be substantially smaller than that", assuming that the discount rate should reflect government discount rates for longterm investments, i.e., a social discount rate in the order of $4 \%$ to $5 \%$. Stern (2008) argues for a lower discount rate and proposes that $\mathrm{CO}_{2}$ prices should be around US\$30/ton $\mathrm{CO}_{2}$. Further analysis of the price of $\mathrm{CO}_{2}$ emissions and the value of $\mathrm{CO}_{2}$ sequestration is outside of our scope, and for the purpose of this analysis a conservative avoided marginal damage cost of 10 euro/ton $\mathrm{CO}_{2}$ is assumed. This means that the total economic benefits of carbon sequestration in above-ground biomass in the park amount to $€ 32,800 /$ year. A nonquantified additional value relates to carbon sequestered in the soil as well as in wood products.

\section{(5) Air pollution removal}

A range of studies have shown that forests remove air pollution by means of dry deposition of pollutants to plant surfaces (Beckett et al. 2000, Nowak et al. 2006). The removal of particles from ambient air generates an economic benefit, related to increased well-being and reduced sickness due to air pollution (Hall et al. 1992). Health impacts of air pollution occur as a function of long-term exposure, and there is still significant uncertainty regarding these effects (Kunzli et al. 2000). 
Consequently, it is difficult to solicit people's willingness to pay for clean air, and data are not available for the Netherlands. This study estimates the value of the air filtration service by estimating the avoided marginal damage costs associated with one unit of particulate matter removal from the atmosphere. These avoided damage costs are estimated at the scale of the whole country, assuming that the avoided damage cost estimate is also valid for the part of the country in which the Hoge Veluwe forest is located, as analyzed in the Discussion section. The avoided marginal damage costs consider only the avoided costs from hospital treatments, and therefore represent an underestimate of the economic value of this service. Hein (2006) estimated the total costs of PM10 pollution in the Netherlands in 2005 to be $€ 1.2$ billion per year plus 12,400 premature deaths. Corrected for $2 \%$ inflation, this amounts to $€ 1.25$ billion in 2007 . The costs were calculated using the WHO (Künzli et al. 2000) methodology, including costs of sick days and hospital treatments for cardiovascular and respiratory diseases, asthma, and bronchitis. In comparison, RIVM (2005) estimated the number of premature deaths due to PM10 air pollution in the Netherlands at between 12,000 and 24,000. Epidemiological studies indicate a linear relationship between PM10 concentration and health effects (Daniels et al. 2000), hence the average costs indicate also the marginal costs of PM10 pollution.

In order to obtain an estimate of the benefits of avoided air pollution due to air filtration by the forests in the park, the total damage costs of PM10 excluding monetized mortality costs for the Netherlands are divided by the total PM10 emitted in the Netherlands. Total PM10 emission in 2006 was 44.85 million $\mathrm{kg}$ PM10 (Milieu en Natuurplanbureau 2006). A correction has to be made for the import of PM10 from abroad, in particular from Belgium with the prevailing southwestern wind, and for PM10 from nonanthropogenic sources. RIVM (2001) estimates that $38 \%$ of PM10 is from national anthropogenic sources. Hence, it is assumed that the damage costs per $\mathrm{kg}$ of PM10 emitted in 2007 amount to $€ 1.25$ billion $/(44.85$ million $\mathrm{kg} / 0.38)=€ 10.6 / \mathrm{kg}$. Note that this excludes the costs of mortality, in view of the difficulties related to estimating the economic costs of a statistical life lost. In comparison, for Belgium, Mayeres et al. (2001) estimate the marginal costs of PM10 emission to be $€ 10 / \mathrm{kg}$ PM10 excluding the costs of mortality and $€ 21 / \mathrm{kg}$
PM10 including the costs of mortality (transformed into 2007 euro on the basis of $2 \%$ inflation per year). The Clean Air for Europe ("CAFE") Project carried out analyses of the damage costs per ton emission for several pollutants in various EU countries. They estimated the marginal damage costs of more dangerous PM2.5 emissions for 2010 to be between $€ 63$ and $€ 180 / \mathrm{kg}$ including the costs of mortality. The large difference between the figures is caused by the different approaches to value premature mortality. Given available literature, the air filtration capacity of trees is related to PM10 rather than PM2.5, and the benefits of the service are conservatively estimated excluding the costs of mortality. The economic benefits related to deposition of PM10 in the Hoge Veluwe park is therefore estimated at $€ 10.6 / \mathrm{kg}$ x avoided emissions of 200 ton/year $=€ 2.1$ million per year.

\section{(6) Recreation: hunting}

The members of the St. Hubertus local hunters' association shoot wild boar and deer according to the quotas determined by the park. They are not allowed to keep the meat and therefore there is no double counting with the meat production service. There are no costs to the foundation for providing the possibility of hunting, and the economic value of this service equals the willingness to pay of the hunters' association for the right to hunt in the area. The hunters' association pays an annual fee of $€ 125,000$ for the exclusive hunting rights in the park. It is possible that the willingness to pay is higher than the actual payment, but this information could not be obtained from the hunters' association. It is therefore assumed that the actual fee reflects the willingness to pay of the hunters' association and, consequently, that it presents a conservative estimate of the economic value generated by this service. Note that the benefits generated by recreational hunting are over two times the benefits generated by the supply of meat, which may be related to the relative scarcity of hunting sites in the Netherlands.

\section{(7) Recreation: walking and cycling}

Both the consumer and the producer surplus are examined. The consumer surplus accruing to visitors to the park is analyzed with the ordinary zonal Travel Cost Method (TCM). This valuation method comprises a number of subsequent steps: 
Table 3. Visitor rates and travel costs to the Hoge Veluwe

\begin{tabular}{|c|c|c|c|c|}
\hline Zone & Total visits/year & Zone population & $\begin{array}{l}\text { Annual visits / } \\
1000 \text { people }\end{array}$ & $\begin{array}{l}\text { Travel costs including entrance } \\
\text { fee (euro) }\end{array}$ \\
\hline $0-15 \mathrm{~km}$ & 32535 & 374,944 & 87 & 10.2 \\
\hline $15-30 \mathrm{~km}$ & 69133 & 999,536 & 69 & 16.0 \\
\hline $30-50 \mathrm{~km}$ & 69133 & $1,567,486$ & 44 & 22.5 \\
\hline $50-100 \mathrm{~km}$ & 113866 & $8,749,474$ & 13 & 35.6 \\
\hline$>100 \mathrm{~km}$ & 20333 & $4,715,285$ & 4 & 52.3 \\
\hline Total & 305,000 & $16,406,724$ & & \\
\hline
\end{tabular}

(1) estimating visitor rates for different zones around the site, (2) estimating travel costs for visitors from these zones, (3) statistical regression, and (4) constructing the demand curve (OECD 1995). It is assumed that all visitors travel to the park by car. This is a simplification, as the 1994 visitor survey shows that $88 \%$ of visitors come by car. Table 3 shows the visit rates per zone, the total population in each of these zones, the visit rate (i.e., visits to the park divided by population, per zone) and the travel costs from each zone to the park. Visits per zone are based on the visitor survey (1994). A basic GIS analysis (ArcGIS/8) of population density in the Netherlands was applied to calculate the zone population. The travel costs are calculated assuming average transport costs by car of 34 eurocent $/ \mathrm{km}$ (based on Rietveld et al. 2000, corrected for $2 \%$ annual inflation) and an average per person hourly wage rate of $€ 4.9$ (Central Planbureau 2008). It is also assumed, based on the visitor survey of 1994, that people travel to the park with on average 2.6 people per car, reducing the per $\mathrm{km}$ travel costs, but not the time costs. The travel time to reach the park is estimated based on the assumption that the first $25 \mathrm{~km}$ of each trip, including driving on the access roads to the park, can be travelled with an average speed of $60 \mathrm{~km} / \mathrm{h}$, and the remainder of the journey, mostly on highways, at $90 \mathrm{~km} / \mathrm{h}$. The entrance fee to the park $(€ 7)$ is added to the travel costs (cf. OECD 1995).

Based on the data presented in Table 3, the relation between travel costs and visit rate can be established. Equation (1) shows the visit rate as a function of the travel costs for the Hoge Veluwe park.

$$
\text { Visit rate }=209.4 e^{-0.0747 * \cos t s} \quad\left(R^{2}=0.96\right)
$$

Subsequently, the demand function for visits to the site has been constructed, under the assumption that expenditure for an entrance fee is viewed in the same way as travel costs by the visitors. The first point on the demand curve is the current amount of visitors to the site (i.e., where the added costs are zero). Subsequent points on the demand curve are calculated for hypothetical increases of the entrance fee ranging from $€ 5$ to $€ 100$ per visit. For the total travel and entrance costs associated with these different fees, the corresponding number of visitors to De Hoge Veluwe has been estimated using Equation (1). The results are presented in Figure 2. The area under the demand curve, equaling the consumer surplus, is around $€ 3.35$ million, which equals around $€ 11$ per visit.

The producer surplus of this service accrues to the foundation managing the Hoge Veluwe park. The individual producer surplus is a function of the revenues minus the costs of offering the service. In 2007, the total revenues the foundation obtained from entrance fees amounted to $€ 3.721$ million. However, the foundation faces a number of costs related to providing recreational facilities. Costs arise, among others, from maintaining and staffing three entrance points where tickets are sold, maintaining and staffing a visitors center, maintaining bicycle paths and parking spaces, and 
Table 4. Ecosystem services supplied by the Hoge Veluwe park

\begin{tabular}{lcl}
\hline \hline Service & $\begin{array}{c}\text { Value } \\
(1000 \text { euro/year })\end{array}$ & Valuation approach \\
\hline Wood production & 354 & Preference based \\
Game (deer and wild boar meat) & 50 & Preference based \\
Groundwater infiltration & 1,950 & Cost-based \\
Carbon capture & 33 & Cost-based (conservative estimate) \\
Air pollution removal & 2,100 & Cost-based (conservative estimate) \\
Recreational hunting & 125 & Preference based (conservative estimate) \\
Recreation & 6,140 & Preference based \\
Nature conservation & - & Not expressed in monetary terms \\
Total & 10,750 & \\
\hline
\end{tabular}

for administration and ICT support. The total costs that can be allocated to the provision of recreational facilities amount to $€ 936,000$ (B. Boers, Hoge Veluwe National Park Foundation, 2010, personal communication). Therefore, the producer surplus generated by the recreational service can be estimated to be $€ 3.721$ million $-936,000=€ 2.785$ million per year. The total value of the recreation service, i.e., the sum of the consumer and producer surplus is therefore 3.35 plus $2.785=€ 6.14$ million.

A summary of the economic value generated per service is provided in Table 4. As previously mentioned, the nature conservation service is not expressed in monetary terms. The estimated total economic value generated by the services supplied by the forest ecosystem of the Hoge Veluwe park is around $€ 10.8$ million per year. This translates to around $€ 2000 /$ ha/year. Note that the value estimate represents a minimum value. The nature conservation service could not be quantified in monetary terms. Given the importance of the park for the conservation of a number of species in the Netherlands, the value is nevertheless likely to be significant. In addition, the value estimates for the recreational hunting service and carbon sequestration are minimum values. This is the case for recreational hunting because the actual willingness to pay for hunting opportunities may exceed the current payment, and in the case of carbon sequestration because carbon capture in soils and wood products is not accounted for. The value estimate for the air filtration study is relatively uncertain, as will be further discussed, and is based on the costs of hospital treatments and sick days only, instead of people's willingness to pay for reduced exposure to air pollution. In addition, it does not account for the costs of mortality. Hence, this value estimate is also likely to be an underestimate. Finally, option values are excluded from the calculations. Hence, the estimate of the total economic value generated by the park of $€ 10.8$ million per year is an indication of the minimum value of the services provided by the forest. The implications of the value estimate will be further discussed.

\section{DISCUSSION}

\section{Uncertainties in the calculations}

The uncertainties in the value assessment stem from both the biophysical quantification and the economic valuation step. The degree of uncertainty varies strongly per service. For the provisioning services of wood production and provision of meat, both biophysical quantification and economic valuation are relatively straightforward. Both 
Fig. 2. Recreation service: demand curve for visits to the Hoge Veluwe

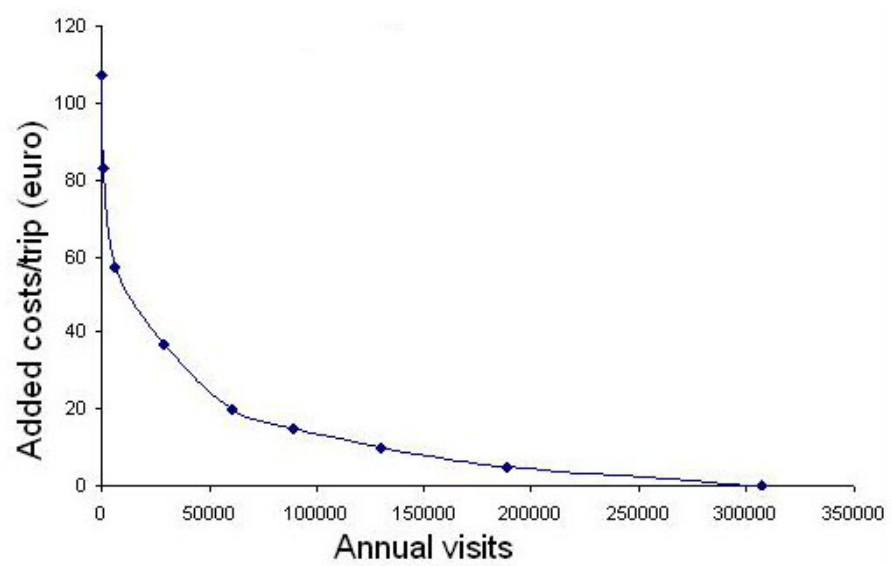

services are a source of revenue for the park and their supply is therefore monitored by park management. For the groundwater infiltration service, uncertainty relates in particular to the applied valuation method. For this service, the replacement cost method is used, which bases the estimate of the benefits of an ecosystem service on the avoided costs of replacing the service and is therefore not preference-based (Freeman 1993). The replacement cost method is appropriate in the case of the groundwater recharge service because the same product, drinking water, would otherwise be supplied based on treated river water (National Research Council 2004).

Carbon sequestration was calculated on the basis of an estimate of the annual wood increment by the foresters of the park, as documented in Nationale Park de Hoge Veluwe (2005). The rate of carbon capture in the above-ground biomass was in line with estimates for other Dutch deciduous and coniferous forests (Sikkema and Nabuurs 1994). It is assumed in this study that the economic value of this service can be estimated based on the marginal damage costs of one unit of carbon. However, this damage cost is prone to uncertainty, because of uncertainty in the processes guiding climate change and its impacts, as well as the discount rate to be used to compare future and present costs (compare Tol 2005 and Stern 2008).

Air filtration is another significant service provided by the park, but there is high uncertainty regarding:
(1) the amount of PM10 being deposited, (2) the subsequent impact on air quality, and (3) the value of this service. There are currently no measurements of PM10 deposition in the park, and this analysis uses figures from the UK, where high variation in PM10 deposition rates was found (Broadmeadow et al. 1998). Second, there is uncertainty regarding the reduction in ambient PM10 concentration as a consequence of air filtration in the park (see also Bealey et al. 2007). In comparison, a study in the UK (Willis et al. 2003) assumed that health benefits from air filtration by forests only occur at short distances $(<1 \mathrm{~km})$ from the forest. European Commission (2005), however, states that damage assessments of particulate matter pollution need to consider that PM pollution can spread over distances of several hundreds of kilometers from an emission source. Therefore, in this study it is assumed that air pollution removal needs to be studied at a broader scale. Specifically, it is assumed that the benefits of a unit of PM10 deposition in the forest can be related to the national average of the marginal costs of PM10 pollution. This assumption seems justified because both the population density in the area (384 people $/ \mathrm{km}^{2}$ compared to 452 people/ $\mathrm{km}^{2}$ for the Netherlands) and the annual average PM10 concentration in ambient air (in both cases around $30 \mu \mathrm{g} / \mathrm{m}^{3}$, RIVM 2005) are in line with the national average. Thirdly, there is high uncertainty regarding the economic value of this service. This study uses costs of medical treatment as an indicator for economic value, but it would be more appropriate to use the willingness to pay of people 
to avoid sickness and hospital treatments (e.g. Hall et al. 1992). In addition, there is uncertainty regarding the economic value of avoided statistical mortality (Pervin et al. 2008). In response to these various uncertainties, the study presents a conservative value estimate, which excludes the value of avoided mortality, and only considers part of the value of avoided morbidity (i.e., sick days and hospital treatment costs).

As for the cultural services, data on visitors and their point of origin were available, and the zonal travel cost method is applied, which results in a theoretically correct estimate of the consumer surplus (Freeman 1993). The producer surplus could be derived from park statistics, and the value estimate for this service is relatively certain. For the nature conservation service, there is increasing literature on quantifying this service in ecological terms. Indicators may focus on species diversity (e.g. Humphries et al. 1995), presence of endangered species (e.g. Ando et al. 1998), or the naturalness of ecosystems (e.g. Ten Brink and Tekelenburg 2002). However, there is ongoing debate on the possibilities of expressing biodiversity in monetary indicators (e.g. Cummings and Harrison 1995, Nunes and Van den Bergh 2004), and the uncertainty involved was deemed too high to value this service of the park in economic terms.

The outcomes of this study can be compared to the results of a national assessment of the social and environmental benefits of forests in England, Scotland, and Wales (Willis et al. 2003). The average annual value provided by recreation, carbon sequestration, and air filtration in English forests is around $€ 2100$ per ha (at 2003 exchange rates and corrected for inflation). Willis et al. (2003) also analyzed the landscape service, reflecting willingness to pay for forested landscapes seen either from home or during a journey. This service is, however, likely to be very small for the Dutch forest because of the absence of public roads in the forest and the limited number of houses with a view of the forest.

\section{Contribution of the Hoge Veluwe protected area to Dutch society}

The net economic benefits generated by the Hoge Veluwe forest depend on the value of the various ecosystem services, as well as the payments received from society. In terms of contributions from society for preserving the park, the foundation that manages the park receives two subsidies: a provincial subsidy for managing the meadows in the park, and a national subsidy for conserving heather. These subsidies are used for the extensive management of the 50 ha of meadows in the park for maintaining heather vegetation that is otherwise likely to disappear due to atmospheric deposition of plant nutrients. The total amount from both subsidies amounts to $€ 188,000$ per year, which is very small compared to the benefits provided by the park to society (around $€ 10.8$ million per year).

The question arises as to how the economic value of the park compares to the value of alternative land uses. Residential land provides by far the highest value per hectare in the surrounding area (Willemen et al. 2010a). Large-scale housing construction would have impacts on the overall house prices in the area, and the modeling required to examine this effect is outside the scope of this study. In order to provide an indication of the relative value of the park with its current forest and heather cover, a comparison is therefore made with the value generated by nearby agricultural land.

The annual rent paid for nearby agricultural land is on average around $€$ 375/ha/year (Central Bureau for Statistics the Netherlands 2009b). The rent paid for cropland near the Hoge Veluwe park is representative of the country as a whole (Central Bureau for Statistics the Netherlands 2009b), and it is high compared to the rent paid for agricultural land in other European countries (Hoogwijk et al. 2009). However, this rent only reflects the capacity of the land to support agriculture. It therefore does not equal the economic value of agricultural land to society, as it omits potential ecosystem services that can be provided by agricultural land, as well as potential negative externalities of agricultural land, such as eutrophication of surface water and unpleasant odor when manure is spread on the fields. In addition to supporting agricultural production, potential additional services of cropland are: (1) drinking water infiltration, (2) biodiversity conservation, (3) supporting recreation by providing an attractive landscape, and (4) carbon sequestration.

The ecosystem services provided in the Gelderse Valley agricultural landscape, adjacent to the park, have been examined by Willemen et al. (2010a) and Willemen et al. (2010b). The Gelderse Valley is a $750 \mathrm{~km}^{2}$ watershed that comprises a mix of urban 
areas, intensive and extensive agriculture land, and small patches of forest. Agricultural land covers around $71 \%$ of the valley. Willemen estimated the value of drinking water infiltration in the valley to be around $€ 4600 /$ ha, but only for those areas that are managed as drinking water protection zones, which cover around 5\% of the valley. In other areas, intensive agriculture leads to infiltration of water polluted with nitrogen and pesticide residues making the water less suitable for drinking water production. Furthermore, although extensively managed meadows are important for both bird and plant life, intensively managed agricultural land generally has low biodiversity (Kleijn et al. 2004, Willemen et al. 2010b). However, the mix of agricultural land and other land uses dissected by small rivers supports recreation, in particular cycling day trips from residents of nearby towns and villages. The surplus generated by local day trips, based on WTP estimates for comparable types of recreational activities in the Netherlands, was estimated by Willemen et al. (2010b) to be on average $172 € / \mathrm{ha} /$ year for the overall area. There is also tourism in the valley, but visitors from other parts of the country by and large come to visit the nearby national parks and forests (ZKA 2004), such as the Hoge Veluwe, and benefits from tourism cannot be attributed to cropland in the Gelderse Valley. Carbon sequestration can be assumed to be very low or even negative in Dutch arable land (Vleeshouwers and Verhagen 2002). Hence, the economic value generated by cropland can be roughly estimated at $550 € / \mathrm{ha} /$ year, accounting for the two services: (1) supporting agriculture, and (2) providing opportunities for recreation, and this is not accounting for potential negative externalities. Consequently, the economic value generated by the Hoge Veluwe national park exceeds that of nearby cropland by a factor of over three.

\section{Policy implications}

The study shows how park management can influence the overall supply of ecosystem services, and that increasing the supply of a specific ecosystem service may lead to an increase or a decline in the provision of other services. For instance, coniferous trees have a relatively high capacity to filter air particles, but also have a relatively high evapotranspiration rate that reduces groundwater infiltration. Changes in park management are likely to affect ecosystem services in a different manner, and their multiple impacts should be considered in park management. Since the park does not receive any payment for the regulating services provided to society, namely groundwater infiltration, air filtration, and carbon sequestration, there may be little incentive to optimize the supply of these public services unless payments for activities that influence ecosystem service supply can be secured. This has happened in the past, when the foundation received a payment from the local drinking water company to cover the costs of expanding the drift sand areas, which had a positive impact on both the nature conservation and the groundwater infiltration service (B. Boers, Hoge Veluwe National Park Foundation, 2008, personal communication).

In the case of the Hoge Veluwe forest, there appeared to be relatively little scope for enhancing park income through Payment for Ecosystem Services schemes (PES) (UNEP 2005, Pagiola 2008, Wunder et al. 2008). The two most valuable services for which the park receives no compensation are the groundwater infiltration service and air filtration. However, for the air filtration service, there is high uncertainty on the physical and economic dimensions of the provided service, and the number of beneficiaries is very high, with each beneficiary receiving only a small benefit. For the groundwater infiltration service the main constraints are that there is a long history of groundwater extraction around the park, and that, according to Dutch law, there are no formal ownership arrangements in place for groundwater aquifers. This single case study does not allow for any general statements regarding the potential of PES, but it does illustrate some limitations of PES in spite of the high economic values of some of the services involved.

The Hoge Veluwe park has a successful business model based on income earned from recreation. Both the high number of annual visitors, and the willingness of visitors to pay a $€ 7$ entrance fee for visiting the Hoge Veluwe are directly related to a number of factors. First, as mentioned, the park is very well known in the country and benefits from a location relatively close to the urban centers in the west of the country. Second, park management undertakes a number of marketing activities, including offering various outdoor activities, such as photography workshops, and providing a number of facilities, such as the free use of bicycles in the park. Third, the park is fenced. The question arises as to whether other protected areas in the country 
have the same possibilities of earning income from recreation. Their options are likely to be more limited, in particular because most other organizations receive government subsidies under the condition that they not charge entrance fees. In addition, it is unsure how large the national market is for "upmarket" national parks charging entrance fees. Consequently, in the face of decreasing government support, other parks may be better off exploring the possibility of offering additional paid services, such as parking facilities and thematic workshops, among others.

\section{CONCLUSIONS}

This study shows the high economic returns that can be generated by protected forest ecosystems in densely populated northwestern Europe. A conservative estimate of the economic benefits generated by the Hoge Veluwe forest is around $€ 10.8$ million per year, i.e., $€ 2000 /$ ha/year, which is over three times the value generated by nearby agricultural land. Over $90 \%$ of this value is generated by only three services: recreation, groundwater infiltration, and air filtration. The benefits from nature conservation have not been quantified in monetary terms. The uncertainties in the value estimates are high for most regulating services, in particular for air filtration. In response to these uncertainties, the study presents a conservative estimate. The examined park is able to thrive without significant government subsidies, because the land is privately owned and fenced, and the park is one of the most well-known and most visited parks in the country. It is therefore able to generate significant income from entrance fees. The case study illustrates the fact that despite the high economic value of generated ecosystem services, the possibilities for generating additional income for park management from PES may be limited. For parks that provide substantial economic benefits but are not able to charge entrance fees or engage in PES, governments should be cautious in limiting support for protected areas, even in the face of the current economic constraints. Park managers should proactively communicate the economic benefits of protected areas to the public and policy makers in order to maintain support for protected area management.
Responses to this article can be read online at: http://www.ecologyandsociety.org/vol16/iss2/art13/ responses/

\section{Acknowledgments:}

I would like to thank Bart Boers and Monique Kokke from the Foundation National Park Hoge Veluwe for providing data and support to this study. In addition, I want to thank Frans Rip for carrying out the GIS analysis supporting the TCM, and Rik Leemans for comments and suggestions.

\section{LITERATURE CITED}

Ando, A., J. Camm, S. Polasky, and A. Solow. 1998. Species distributions, land values, and efficient conservation. Science 279:2126-2128.

Ansink, E., L. Hein, K. P. Hasund. 2008. To value functions or services? An analysis of ecosystem valuation approaches. Environmental Values 17 (4):489-503.

Balmford, A., A. Bruner, P. Cooper, R. Costanza, S. Farber, R. Green, M. Jenkins, P. Jefferiss, V. Jessamay, J. Madden, K. Munro, N. Myers, S. Naeem, J. Paavola, M. Rayment, S. Rosendo, J. Roughgarden, K. Trumper, and R. K. Turner. 2002. Economic reasons for conserving wild nature. Science 297:950-953.

Balmford, A., and T. Whitten. 2003. Who should pay for tropical conservation, and how could the costs be met? Oryx 37:238-250.

Bastiaanssen, W., and H. Roozekrans. 2003. Vlakdekkende actuele verdamping van Nederland. Stromingen 9(4): 5-19.

Bealey, W. J., A. G. McDonald, E. Nemitz, R. Donovan. 2007. Estimating the reduction of urban PM10 concentrations by trees within an environmental information system for planners. Journal of Environmental Management 85:44-58.

Beckett, K. P., P. H. Freer-Smith, G. Taylor. 2000. Particulate pollution capture by urban trees: effect of species and windspeed. Global Change Biology 6(8):995-1003. 
Bockstael, N. E., A. M. Freeman, III, R. J. Kopp, P. R. Portney, and, V. K. Smith. 2000. On measuring economic values for nature. Environmental Science \& Technology 34(8):1384-1389.

Boyd, J., and S. Banzhaf. 2007. What are ecosystem services? The need for standardized environmental accounting units. Ecological Economics 63(23):616-626.

Brauer, I. 2005. Valuation of ecosystem services provided by biodiversity conservation: an integrated hydrological and economic model to value the enhanced nitrogen retention in renaturated streams. Pages 193-204 in M. Markussen, editor. Valuation and conservation of biodiversity. Springer, Berlin, Germany.

Broadmeadow, M., K. P. Beckett, S. Jackson, P. H. Freer-Smith, and G. Taylor. 1998. Trees and pollution abatement. Pages 39-43 in Forestry Commission report on forest research. HMSO, London, UK.

Carpenter, S. R., R. DeFries, T. Dietz, H. A. Mooney, S. Polasky, W. V. Reid, R. J. Scholes. 2006. Millennium Ecosystem Assessment: research needs. Science 314:256-257

Carpenter, S. R., H. A. Mooney, J. Agard, D. Capistrano, R. S. DeFries, S. Díaz, T. Dietz, A. K. Duraiappah, A. Oteng-Yeboah, H. M. Pereira, C. Perrings, W. V. Reid, J. Sarukhanm, R. J. Scholes, and A. Whyte. 2009. Science for managing ecosystem services: beyond the Millennium Ecosystem Assessment. Proceedings of the National Academy of Sciences of the United States of America 106(5):1305-1312.

Central Bureau for Statistics the Netherlands (CBS). 2009a. Statline on-line statistical database. [online] URL: http://statline.cbs.nl/StatWeb/publication/?DM= $\underline{S L N L \& P A=80111 N E D \& D 1=0 \& D 2=40,71,224,30}$ 4,337,421-423,956-1032,1095,1141,1286,1299,143 $\underline{6,1502,1752,2049,2383,2404 \& D 3=1 \& H D R=G 1, T \& S T B=}$ G2\&CHARTTYPE $=1 \& V W=T$. Accessed 10 March 2009.

Central Bureau for Statistics the Netherlands (CBS). 2009b. Statline on-line statistical database. [online] URL: http://www.cbs.nl/nl-NL/menu/themas/landbouw/ publicaties/artikelen/archief/2003/2003-1103-wm.htm . Accessed 10 March 2009.
Central Planbureau (CPB). 2008. Centraal economisch plan (English translation: Central economic plan). Central Planbureau, Ministry of Economic Affairs, the Hague, the Netherlands.

Cicchetti, C. V., and A. M. Freeman. 1971. Option demand and consumer surplus, further comment. Quarterly Journal of Economics 85:528-539.

Cummings, R. G., and G. W. Harrison. 1995. The measurement and decomposition of nonuse values: a critical review. Environmental and Resource Economics 5(9):225-247.

Daily, G. C., and P. A. Matson. 2008. Ecosystem services: from theory to implementation. Proceedings of the National Academy of Sciences of the United States of America 105:9455-9456.

Daily, G. C., S. Polasky, J. Goldstein, P. M. Kareiva, H. A. Mooney, L. Pejchar, T. H Ricketts, J. Salzman, and R. Shallenberger. 2009. Ecosystem services in decision making: time to deliver. Frontiers in Ecology and the Environment 7:21-28.

Daniels, M. J., F. Dominici, J. Samet, S. L. Zeger. 2000. Estimating particulate matter-mortality doseresponse curves and threshold levels: an analysis of daily time-series for the 20 largest US cities. American Journal of Epidemiology 152(5):397-406.

Dearden, P., M. Bennett, and J. Johnston. 2005. Trends in global protected area governance 19922002. Environmental Management 36:89-100.

Elsasser, P. and J. Meyerhoff. 2007. A bibliography and database on environmental benefit valuation studies in Austria, Germany and Switzerland. Part I: Forestry Studies. Arbeitsbericht. Bundesforschungsanstalt für Forst- und Holzwirtschaft, Hamburg, Germany.

Emerton, L., J. Bishop, and L. Thomas. 2006. Sustainable financing of protected areas: a global review of challenges and options. IUCN, Gland, Switzerland and Cambridge, UK.

European Commission. 2005. ExternE- Externalities of energy. Methodology 2005 Update. European Commission, Brussels, Belgium.

Freeman, A. M. 1993. The measurement of environmental values and resources. Resources for the future. Washington, D.C., USA. 
Garrod, G. D., and K. G. Willis. 1997. The non-use benefits of enhancing forest biodiversity: a contingent ranking study. Ecological Economics 21:45-61.

Gaston, K. J, S. F. Jackson, A. Nagy, L. CantúSalazar1, M. Johnson. 2008. Protected areas in Europe: principle and practice. Annals of the New York Academy of Sciences 1134:97-119.

Gehrels, J. C., and A. J. Dolman. 1996. Veluwemodelberekening op basis van nieuwe

bosverdampingsgegevens (English translation: Veluwe model on the basis of new forest evaporation figures). $\mathrm{H} 2 \mathrm{O}$ 29:753-754.

Hall, J., A. Winer, M. Kelinman, F. Lurmann, V. Brajer, and S. D. Colome. 1992. Valuing the health effects of clean air. Science 255(5046):812-817.

Hein, L. 2006. De kosten van $\mathrm{PM}_{10}$ luchtverontreiniging in Nederland (English translation: The costs of $\mathrm{PM}_{10}$ air pollution in the Netherlands). Milieu 5:22-27.

Hein, L., K. van Koppen, R. S. de Groot, and E. C. van Ierland. 2006. Spatial scales, stakeholders and the valuation of ecosystem services. Ecological Economics 57(2):209-228.

Hoogwijk, M., A. Faaij, B. de Vries, and W. Turkenburg. 2009. Exploration of regional and global cost-supply curves of biomass energy from short-rotation crops at abandoned cropland and rest land under four IPCC SRES land-use scenarios. Biomass and Bioenergy 33:26-43.

Humphries, C. J., P. H. Williams, and R. I. VaneWright. 1995. Measuring biodiversity value for conservation. Annual Review of Ecology and Systematics 26:93-111.

Jansen, M., J. W. Te Kloeze, and J. L. M. van der Vloet. 1994. Recreatieonderzoek Nationale Park De Hoge Veluwe 1994 (English translation: Recreation survey of the Hoge Veluwe National Park). Report Nr. 40. Recreation and Tourism Study Group, Wageningen University, Wageningen, the Netherlands.

Jongeneel, R., N. Polman, and L. Slangen. 2008. Cost-benefit analysis of the Dutch nature conservation policy: direct, indirect effects and transaction costs of the ecological main structure in the Netherlands. Pages 1-9 in Proceedings of the 12th Congress of the European Association of Agricultural Economists. EAAE, Ghent, Belgium.

Kleijn, D., F. Berendse, N. Gilissen, J. Smit, B. Bark, and R. Groeneveld. 2004. The ecological effectiveness of agri-environment schemes in different agricultural landscapes in The Netherlands. Conservation Biology 18:775-786.

Künzli, N., R. Kaiser, S. Medina , M. Studnicka , O. Chanel, P. Filliger, M. Herry, F. Horak, Jr, V. Puybonnieux-Texier, and P. Quénel. 2000. Publichealth impact of outdoor and traffic-related air pollution: a European assessment. The Lancet 356:795-801.

Mayeres, I., S. Proost, D. Vanderdruyssen, L. De Nocker, L. Panis, G. Wouters, and B. de Borger. 2001. The external costs of transportation. Centre for Economic Studies, Leuven, Belgium.

Milieu en Natuur Planbureau. 2005. Fijn stof nader bekeken, de stand van zaken in het dossier fijn stof. RIVM, Bilthoven, the Netherlands.

Milieu en Natuur Planbureau. 2006. Haalbaarheid nationale emissieplafonds in 2010 (English translation: Feasibility of national emission ceilings in 2010). Milieu en Natuur Planbureau, Bilthoven, the Netherlands.

Millennium Assessment. 2003. Ecosystems and human well-being: a framework for assessment. Island Press, Washington, D.C., USA.

Millennium Assessment. 2005. Volume I. Ecosystems and human well-being: current state and trends. Island Press, Washington, D.C., USA.

Mulder, M. 1998. Economische graadmeters voor natuur: ontwikkeling raamwerk en aanzet tot invullling verdelingsgraadmeters. Agricultural Economics Research Institute, The Hague, the Netherlands.

Nationale Park de Hoge Veluwe (NPHV). 2005. Nature management plan. Foundation National Park Hoge Veluwe, Hoenderlo, The Netherlands.

National Research Council. 2004. Valuing ecosystem services: toward better environmental decision-making. National Research Council, Washington, D.C., USA. 
Nelson, E., G. Mendoza, J. Regetz, S. Polasky, H. Tallis, D. R. Cameron, K. M. A. Chan, G. C. Daily, J. Goldstein, P. M. Kareiva, E. Lonsdorf, R. Naidoo, T. H. Rickets, and M. R. Shaw. 2009. Modeling multiple ecosystem services, biodiversity conservation, commodity production, and tradeoffs at landscape scales. Frontiers in Ecology and the Environment 7 (1):4-11.

Nowak, D. J., D. E. Crane and J. C. Stevens. 2006. Air pollution removal by urban trees and shrubs in the United States. Urban Forestry Urban Greening 4(6):115-123.

Nunes, P., and J. van den Bergh. 2004. Can people value protection against invasive marine species? Evidence from a Joint TC-CV Survey in the Netherlands. Environmental \& Resource Economics 28(4):517-532.

OECD. 1995. The economic appraisal of environmental projects and policies: a practical guide. Organisation for Economic Development and Cooperation, Paris, France.

Pagiola, S. 2008. Payments for environmental services in Costa Rica. Ecological Economics 65:712-724.

Palomo I., B. Martín-López, C. López-Santiago, and C. Montes. 2011. Participatory scenario planning for protected areas management under the ecosystem services framework: the Doñana SocialEcological System in Southwestern Spain. Ecology and Society 16(1):23. [online] URL: http://www.ec ologyandsociety.org/vol16/iss1/art23/

Parviainen, J., and G. Frank. 2003. Protected forests in Europe - harmonizing the definitions for international comparison and forest policy making. Journal of Environmental Management 67:27-36.

Pervin, T., U. G. Gerdtham, and C. Hampus Lyttkens. 2008. Societal costs of air pollutionrelated health hazards: A review of methods and results. Cost Effectiveness and Resource Allocation 6(19). [online] URL: www.resource-allocation.com/ content $/ 6 / 1 / 19$

Planbureau voor de Leefomgeving (PBL). 2009. Compendium voor de Leefomgeving. Netherlands Environmental Assessment Agency, Bilthoven, the Netherlands 2009.
Planbureau voor de Leefomgeving (PBL). 2010. Balans van de Leefomgeving. Netherlands Environmental Assessment Agency, Bilthoven, the Netherlands.

Powe, N. A. and K. G. Willis. 2004. Mortality and morbidity benefits of air pollution (SO2 and PM10) absorption attributable to woodland in Britain. Journal of Environmental Management 70 (2):119-128.

Ragland, K.W, D. J. Aerts, and A. J. Baker. 1991. Properties of Wood for combustion analysis. Bioresource Technology 37(9):161-168.

Rietveld, P., B. Ubbels, and P. M. Peeters. 2000. Effectiviteit en haalbaarheid van een geavanceerde kilometerheffing (English translation: Effectiveness and feasibility of an advanced kilometer tax). Report. Free University of Amsterdam, Amsterdam, the Netherlands.

RIVM. 2001. Composition and origin of airborne PM in the Netherlands. RIVM Report 650010029. RIVM, Bilthoven, the Netherlands.

RIVM. 2005. Fijn stof nader bekeken (English translation: Particulate matter: a closer look). Milieu en Natuurplanbureau, Bilthoven, the Netherlands.

RIVM. 2006. Gevalideerde meetgegevens Landelijk Meetnet Luchtkwaliteit (English translation: Validated measurements of the National Air Quality Inventory). RIVM, Bilthoven, 2006. [online] URL: http://www.lml.rivm.nl/data/tabel/actueel.html. Accessed 2 September 2010.

Sikkema, R., and G. J. Nabuurs. 1994. Forests and wood on the carbon balance. Foundation Bos and Wood, Wageningen, the Netherlands.

Soma, K. 2006. Natura economica in Environmental valuation. Environmental Values 15:31-50.

Spash, C. L. 2008. How much is that ecosystem in the window? The one with the bio-diverse trail. Environmental Values 17:259-284.

Spash, C. L., and N. Hanley. 1995. Preferences, information and biodiversity preservation. Ecological Economics 12:191-208. 
Stern, N. 2008. The economics of climate change. American Economic Review: Papers \& Proceedings 98:2-37.

Tallis, H., R. Goldman, M. Uhl, and B. Brosi. 2009. Integrating conservation and development in the field: implementing ecosystem service projects. Frontiers in Ecology and the Environment 7:1220 .

Tauw. 2003. Modelstudie grondwaterstromingen in de Veluwe (English translation: Modelling of groundwater flows in the Veluwe). Tauw Consultants, Rotterdam, the Netherlands.

Ten Brink, B. J. E., and T. Tekelenburg. 2002. Biodiversity: how much is left? The Natural Capital Index framework (NCI). RIVM report 402001014. RIVM, Bilthoven, the Netherlands.

Tol, R. S. J. 2005. The marginal damage costs of carbon dioxide emissions: an assessment of the uncertainties. Energy Policy 33(2):2064-2074.

Turner R. K., and G. C. Daily. 2008. The ecosystem services framework and natural capital conservation. Environmental and Resource Economics 39 (1):25-35.

Turner, R. K., C. J. M. van den Bergh, T. Soderqvist, A. Barendregt, J. van der Straaten, E. Maltby, and E. C. van Ierland. 2000: Ecological-economic analysis of wetlands: scientific integration for management and policy. Ecological Economics 35 (4):7-23.

United Nations Environment Program. 1997. Recommendation for a core set of indicators of biological diversity. Convention of Biological Diversity. UNEP/CBD/SBSTTA/3/9, and inf. 13, inf. 14. Montreal, Quebec, Canada.

United Nations Environment Program. 2005. Discussion paper on multilateral environmental agreements and pro-poor markets for ecosystem services. UNEP, Nairobi, Kenya.

Varian, H.R. 1993. Intermediate micro-economics. Third edition. W.W. Norton \& Company, New York, USA.

Vewin. 2007. Water in zicht, Bedrijfsvergelijking in de drinkwatersector. [online] URL: http://www.vew
in.nl/SiteCollectionDocuments/Publicaties/Overige\% 20Vewin-uitgaven/2007/Water\%20in\%20zicht\%202006. pdf. Accessed 12 December 2008.

Vitens. 2008. De Veluwe als bron van veilig drinkwater (English translation: The Veluwe as a source of drinking water). Vitens, Utrecht, the Netherlands.

Vleeshouwers, L. M. and A. Verhagen. 2002. Carbon emission and sequestration by agricultural land use: a model study for Europe. Global Change Biology 8:519-530.

Waterwatch. 2007. SEBAL vs. Makkink, wat zijn de verschillen?. Waterwatch Report, Wageningen, the Netherlands.

Willemen, L., L. Hein, and P. Verburg. $2010 a$. Evaluating the impact of regional development policies on future landscape services. Ecological Economics 69(11):2244-2254.

Willemen, L., L. Hein, M. E. F van Mensvoort and P. H. Verburg. 2010b. Space for people, plants, and livestock? Quantifying interactions among multiple landscape functions in a Dutch rural region. Ecological Indicators 10(1):62-73.

Willis, K. G., G. Garrod, R. Scarpa, N. Powe, A. Lovett, I. J. Bateman, N. Hanley, and D. C. Macmillan. 2003. The social and environmental benefits of forests in Great Britain. Centre for Research in Environmental Appraisal \& Management, University of Newcastle, UK.

World Bank. 2008. State and trends of the carbon market 2008. World Bank, Washington, D.C., USA.

Wunder, S., S. Engel, and S. Pagiola. 2008. Taking stock: a comparative analysis of payments for environmental services programs in developed and developing countries. Ecological Economics 65 (4):834-852.

ZKA. 2004. Allure dichtbij: betekenis van het Nationale Park de Hoge Veluwe voor toerisme en economie van Gelderland en de Veluwe in het bijzonder (English translation: Significance of the Hoge Veluwe National Park for tourism and the economy of Gelderland and the Veluwe in particular). ZKA Consultants, Breda, the Netherlands. 